Jurnal Ekonomi dan

Manajemen

Teknologi (EMT)
Jurnal Ekonomi dan Manajemen Teknologi,

6(1), 2022, 126-135

Available online at http://journal.lembagakita.org

\title{
Analisis Pengaruh Dana Pihak Ketiga, Total Aset, dan Non- Performing Finance Terhadap Pembiayaan Bagi Hasil
}

\author{
Syawal Harianto ${ }^{1 *}$, Saparuddin Siregar ${ }^{2}$, Sugianto ${ }^{3}$ \\ ${ }^{1 *}$ Politeknik Negeri Lhokseumawe, Kota Lhokseumawe, Provinsi Aceh, \\ Indonesia. \\ 2,3 Universitas Islam Negeri Sumatera Utara, Kabupaten Deli Serdang, Provinsi \\ Sumatera Utara, Indonesia.
}

\begin{abstract}
Abstrak. Tujuan dari penelitian ini adalah untuk. mengetabui dan menganalisis faktor-faktor yang mempengarubi total revenue sharing financing pada unit usaba syariah di Indonesia. Faktor-faktor tersebut adalah Dana Pihak Ketiga (DPK), Non-Performing Financing (NPF), dan Total Aset (TA). Data yang digunakan dalam penelitian ini adalah data panel periode 2010-2020 yang diterbitkan oleh Kementerian Keuangan dan dalam laporan keuangan tabunan perbankan syariah. Populasi sebanyak 21 perusabaan dengan sampel 5 perusabaan dengan metode purposive sampling. Alat analisis yang digunakan adalah Eviews 10 dan SPSS 18. Teknik analisis dalam penelitian ini adalah regresi data panel dengan pengujian menggunakan model fixed effect. Hasil penelitian ini menunjukkan bahwa DPK, NPF, dan TA secara simultan berpengaruh signifikan terhadap total pembiayaan bagi hasil pada unit usaha syariah di Indonesia. Untuk hasil penelitian secara parsial menunjukean bahwa variabel DPK dan TA berpengarub positif signifikan terbadap total pembiayaan pada Unit Usaba Syariah di Indonesia. Variabel NPF tidak berpengaruh negatif signifikan terhadap total pembiayaan pada Unit Usaha Syariah di Indonesia. Hasil nilai R-Square adjusted menunjukean nilai 51,9\%.
\end{abstract}

Kata kunci: DPK, Jumlah Aset; NPWP; Unit Usaha Syariah.

\begin{abstract}
The purpose of this study is to know and analyze the factors that affect total revenue-sharing financing in sharia business units in Indonesia. These factors are Third Party Funds (DPK), Non-Performing Financing (NPF), and Total Assets (TA). The data used in this study is panel data with the period 2010-2020 published by the Financial Ministry and in the annual financial statements of Islamic banking. The population of 21 companies with a sample of 5 companies with purposive sampling methods. The analysis tools used are Eviews10 and SPSS 18. The analysis technique in this study is a regression of panel data by testing using a fixed-effect model. The results of this study showed that DPK, NPF, and simultaneously had a significant effect on total revenue-sharing financing in sharia business units in Indonesia. The results of the study partially showed that the variables of DPK and TA had a significant positive effect on the total financing in the Sharia Business Unit in Indonesia. The NPF variable does not have a significant negative effect on the total financing in the Sharia Business Unit in Indonesia. The results of the R-Square adjusted value showed a value of $51.9 \%$.
\end{abstract}

Keywords: DPK, Total Asset; NPF; Sharia Business Unit.

*Author. Email: syawalharianto@pnl.ac.id ${ }^{1}$, saparuddin.siregar@uinsu.ac.id 2, sugianto@uinsu.ac.id ${ }^{3}$

DOI: https://doi.org/10.35870/emt.v6i1.542

Received: 3 January 2022, Revision: 6 February 2022, Accepted: 8 February 2022, Available Online: 13 February 2022.

Print ISSN: 2579-7972; Online ISSN: 2549-6204.

Copyright@ 2022. Published by Lembaga Otonom Lembaga Informasi dan Riset Indonesia (KITA INFO dan RISET). 


\section{Pendahuluan}

Perbankan syariah di indonesia menunjukkan tren peningkatan yang positif meskipun di tengah pandemic Covid-19, hasil data OJK periode Juni 2020 yaitu jumlah aset, dana pihak ketiga (DPK) dan pembiayaan yang diberikan (PYD) perbankan syariah terus bertumbuh jika disbanding tahun sebelumnya. Peningkatan menjadi indicator yang baik terhadap pertumbuhan ekonomi nasional. Data rekening per Juni 2020 bank syariah mencapai Rp. 45,39 triliun atau YoY BUS mengalami peningkatan sebesar Rp. 377,525 triliun dan Rp. 430,209 triluin. Periode Desember 2019 bank syariah memiliki aset mencapai 350,364 Miliar, jumlah tersebut meningkat dari pada tahun sebelumnya, begitu juga dengan jumlah DPK yang mengalami peningkatan menjadi 288,978 Miliar. Hal ini menjadi bukti masyarakat semakin memahami perbankan syariah. Perkembangan Market Share Perbankan Syariah dari tahun 2013-2019 yang dinilai masih belum mencapai target. Roadmap Perbankan Syariah 2015-2019 target market share perbankan syariah terhadap perbankan nasional adalah sebesar $10 \%$ sedangkan capainya mencapai kisarna $6 \%$ tahun 2019. Sementara tahun 2020 pembiayaan murabahah memiliki nilai sebesar Rp. 136.990 miliar

Selain itu produk produk bank syariah seperti Mudharabah, Musyarakah dan Murabahah merupakan kegiatan pembiayaan berbasis bagi hasil yang dilakukan dengan berbagai paket penyaluran dana kepada masyarakat yang dilakukan berdasarkan prinsip syariah. Penyaluran pembiayaan pada unit usaha syariah masih didominasi oleh pembiayaan Murabahah yang mana dari tahun ke tahun terus mengalami peningkatan kemudian diikuti dengan pembiayaan Mudharabah dan Musyarakah. Dalam melaksanakan kegiatan usahanya, perbankan syariah memberikan pilihan produk kepada nasabah. Pada dasarnya produk perbankan syariah bisa klasifikasikan dalam tiga bentuk, yaitu produk penggumpulan dana atau tabungan, produk pembiayaan, dan jasa untuk nasabah Yudiana dalam (Umum, 2021). Banyaknya nasabah atau deposan yang bergabung dengan bank syariah mendorong aliran dana yang masuk ke dalam cash flow bank syariah semakin tinggi. Meningkatnya aliran dana di dalam cash flow membuat manajemen lebih leluasa untuk melakukan berbagai kegiatan berbasis syariah semakin tinggi. Faktor lain yang mendorong meningkatnya aktifitas pembiayaan di lingkungan bank syariah adalah peningkatan performing bank berbasis syariah yang dapat ditentukan dengan mengamati non-performing financing.

Salah satu kegiatan operasional perbankan syariah adalah memberikan pembiayaan yang dapat membantu masyarakat dalam menjalankan kegiatan usahanya. Undang-undang Nomor 21 Tahun 2008 tentang perbankan Syariah mendefinisiskan pengertian mengenai pembiayaan yang diberikan oleh bank syariah yaitu penyediaan dana atau tagihan yang dipersamakan dengan itu berupa transaksi bagi hasil dalam bentuk mudharabah dan musyarakah; transaksi sewa menyewa dalam bentuk ijarah atau sewa beli dalam bentuk ijarah muntahiya bittamlik; transaksi jual beli dalam bentuk murabahah dan piutang qardh; dan transaksi sewa menyewa jasa dalam bentuk ijarah. Jadi ada beberapa faktor yang mempengaruhi volume pembiayaan pada unit usaha syariah di Indonesia yang perlu di analisis lebih mendalam sehingga akan ditemukan gambaran tentang faktor-faktor apa saja yang akan mempengaruhi volume pembiayaan. Tujuan Penelitian ini 1) Untuk mengetahui apakah variabel Dana Pihak Ketiga (DPK), Total Aset (TA), Non-Performing Financing (NPF), berpengaruh secara simultan pada Terhadap pembiayaan terhadap Unit Usaha Syariah di Indonesia, dan 2) Untuk mengetahui apakah variabel Dana Pihak Ketiga (DPK), Total Aset (TA), Non-performing Financing (NPF), berpengaruh secara parsial pada terhadap pembiayaan unit usaha syariah di Indonesia.

\section{Tinjauan Literatur}

\section{Pembiayaan}

Penyaluran pembiayaan merupakan salah satu fungsi bank syariah, dimana penyaluran dana yang ada pada perbankan syariah merupakan kegiatan bisnis utama. (Wahyuningtyas \& Utami, 2021) Pembiayaan merupakan aktivitas bank syariah dalam menyalurkan dana kepada pihak lain selain bank berdasarkan prinsip syariah. Penyaluran dana dalam bentuk pembiayaan didasarkan pada kepercayaan yang 
diberikan oleh pemilik dana kepada pengguna danaPenyaluran pembiayaan bertujuan untuk mendapatkan manfaat bagi pihak pemberi pinjaman dan membantu untuk kelancaran kegiatan bagi penerima pinjaman Yudiana dalam (Umum, 2021) dan Veithzal Rival dan Arviyan Arifin (2021). Pembiayaan merupakan bentuk pemberian penyediaan dana untuk menuhi kebutuhan pihak-pihak yang merupakan defisit unit (Harianto, 2017) Penyaluran pembiayaan oleh perbankan syariah dilakukan dengan beberapa jenis akad seperti jual beli, kerjasama, sewa menyewa. (Meutia et al., 2019) pembiayaan merupakan salah satu komponen penting bagi bank syariah dalam upaya meningkatkan profitabilitas.

\section{Non-Performing Financing (NPF)}

Non-performing Financing merupakan rasio pembiayaan yang bermasalah dengan total penyaluran dana yang disalurkan kepada masyarakat NPF adalah pembiayaan dengan klarifikasi yang kurang lancar, atau kemungkinan tidak dapat ditagih (Putri \& Purwohandoko, 2021). Non-performing Financing (NPF) atau pembiayaan bermasalah, dengan munculnya NPF akan mengurangi kesempatan untuk perbankan syariah mendapatkan profit dari pembiayaan yang telah disalurkan (Harianto, 2017). Alfonso \& Diana (2021) NPF merupakan pembiayaan bermasalah yang terjadi karena nasabah tidak mampu melunasi pinjamannya, masalah ini terdiri dari pembiayaan dengan kualitas kurang lancar, diragukan, dan macet. Manaf \& Bawono (2019) menyeburkan tingkat pengembalian pembiayaan yang diberikan deposan kepada bank dengan kata lain NPF merupakan tingkat pembiayaan macet pada bank tersebut. mampuan bank dalam mengukur risiko kegagalan pengembalian pinjaman oleh debitur (pihak yang menerima pembiayaan). Wahyuningtyas \& Utami (2021) menjelaskan bahwa NPF digunakan untuk menghitung pembiayaan non lancar terhadap total pembiayaan dalam peraturan Bank Indonesia No. 8/21/PBI/2006 tentang penilaian kualitas bank umum yang melaksanakan kegiatan usaha berdasarkan prinsip syariah pasal 9 ayat (2), bahwa kualitas aktiva produktif dalam pembiayaan dibagi dalam 5 golongan yaitu lancar, dalam perhatian khusus, kurang lancar, diragukan, dan macet (Gusnetti, 1967). Dalam penelitian ini, Non-Performing Financing dapat dirumuskan sebagai berikut:

$$
N P F=\frac{\text { Pembiayaan bermasalah }}{\text { Total Pembiayaan }} \times 100 \%
$$

\section{Dana Pihak Ketiga (DPK)}

DPK merupakan dana yang dikelola untuk mengakomodasi kegiatan operasional bank yang berasal dari masyarakat baik nasabah atau investor kasmir dalam (Putri \& Purwohandoko, 2021). dana simpanan yang bersumber dari titipan masyarakat, untuk pengambilan dananya menggunakan media tertentu dan dapat dilakukan kapan saja Wardiantika dalam (Umum, 2021). Bank syariah dapat menarik dana pihak ketiga dari masyarakat dalam 3 bentuk yaitu, titipan (wadiah), mudhrabah mutlaqah dan mudharabah muqayyadah (Arifin, 2006:48).

Dana Pihak Ketiga merupakan sumber dana bank yang diperoleh dari masyarakat baik dalam bentuk giro, tabungan, maupun deposito. Dana yang dimiliki dalam bentuk penyimpanan bentuk Giro Syariah, Tabungan, dan Deposito (Harianto, 2017). Penghimpunan dana (tidak termasuk modal) perbankan syariah secara umum didominasi oleh Dana Pihak Ketiga (DPK). (Wahyuningtyas \& Utami, 2021) DPK simpanan dana yang dipercayakan oleh masyarakat kepada bank berdasarkan perjanjian penyimpanan dana dalam bentuk giro, tabungan, deposito dan atau bentuk lainnya yang dipersamakan dengan itu. Dalam penelitian ini, simpanan atau dana pihak ketiga dapat dirumuskan sebagai berikut:

Dana Pihak Ketiga $=$ Giro + Tabungan + Deposito

\section{Total Aset}

Aset merupakan sumber ekonomi yang diharapkan memberikan manfaat usaha di masa mendatang Horngren \& Harrison dalam (Nofi Zumaidah \& Soelistyo, 2018). Aset perbankan adalah semua hak yang dimiliki dan dapat digunakan dalam operasi bank umum seperti bangunan, merk dagang, paten, teknologi, uang kas, mobil, dan lain-lain.(Mahdawi et al., 2021). Assets merupakan harta atau kekayaan yang dimilki oleh perusahaan, baik pada saat tertentu maupun periode tertentu (Haryani \& Wiratmaja, 2014) Total aset adalah indikator 
yang menentukan kontribusi perbankan syariah terhadap perbankan nasional serta sebagai suatu indikasi kuantitatif besar kecilnya bank tersebut.

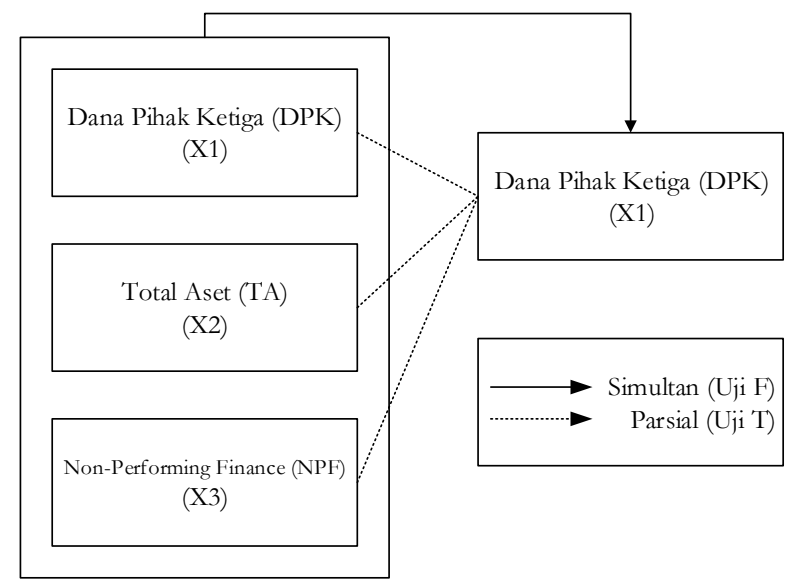

Gambar 1. Kerangka Konseptual

\section{Metodologi Penelitian}

\section{Jenis Data dan Sumber Data}

Jenis penelitian ini menggunakan data kuantitatif yang menggunakan data numerik atau angkaangka yang terdiri dari laporan keuangan, jenis data yang digunakan dalam penelitian ini adalah data sekunder yaitu data panel, yaitu gabungan antara data time series dan data cross section. Sumber data yang digunakan dalam penelitian ini berupa laporan keuangan tahunan yang telah diolah dan dipublikasikan secara umum yang dapat diperoleh dari statistik perbankan syariah dan website perusahaan yang terkait dari periode 2010 sampai dengan periode 2020 .

\section{Populasi Dan Sampel}

Populasi yang digunakan dalam penelitianini sebanyak 21 perusahaan dan sampel sebanyak 5 perusahaan dengan teknik pengambilan sampel secara purposive sampling.

\section{Metode Analisis Data}

Metode analisis data yang digunakan dalam penelitian ini adalah analisis regresi linier berganda. Metode analasis ini digunakan untuk mengetahui pengaruh variabel dependen dan variabel independen dua atau lebih. Persamaan yang dapat dirumuskan untuk menguji hipotesis dalam penelitian ini digunakan model sebagai berikut:

$$
\begin{aligned}
& Y=\alpha+\beta 1 D P K+\beta 2 T A+\beta 3 N P F+\varepsilon \\
& \text { Ln Pembiayaan }=\alpha+\beta 1 \operatorname{LnDPK}+\beta 2 \operatorname{LnTA} \\
& +\beta 3 N P F+\varepsilon
\end{aligned}
$$

Keterangan:

Y : Pembiayaan

$\alpha \quad$ : Konstanta

$\beta \quad:$ Koefisien Regresi

$\varepsilon \quad:$ Error Term

NPF : Non-performing Financing

DPK : Dana Pihak Ketiga

TA : Total Aset

Ln : Logaritma Natural.

\section{Hasil dan Pembahasan}

\section{Analisis Deskriptif}

Jenis data yang digunakan dalam penelitian ini adalah berupa data panel, yakni gabungan antara data runtut waktu (time series) dan data silang (cross section). Data runtut waktu (time series) tahunan untuk periode 2010 sampai dengan 2020. Data silang (cross section) meliputi lima bank yang menerbitkan laporan keuangan secara kontinyu, yakni Bank Pembangunan Daerah DKI, Bank Pembangunan Daerah Kalimanatan Selatan, Bank Pembangunan Daerah DIY, Bank Pembangunan Daerah Kalimantan Timur dan Utara, Bank Pembangunan Daerah Sumatera Barat. Berdasarkan ketersediaan data dari laporan tahunan sebanyak 45 data maka data tersebut dianggap telah representatif. Dibawah ini adalah deskripsi data yang digunakan dalam penelitiaan ini yang telah diolah dengan menggunakan eviews: 
Tabel 1. Hasil Statistik Deskriptif

\begin{tabular}{lllll}
\hline & Pembiayaan & Dana Pihak Ketiga & Total Aset & Non perfroming Loan \\
\hline Mean & 27.20497 & 27.58707 & 28.10773 & 2.565333 \\
Median & 27.25691 & 27.06487 & 27.76030 & 2.360000 \\
Maximum & 29.08217 & 31.30671 & 31.63325 & 5.800000 \\
Minimum & 24.81583 & 24.91730 & 25.91444 & 0.090000 \\
Std. Dev. & 0.957678 & 1.758221 & 1.635397 & 1.537570 \\
Skewness & 0.007794 & 1.048728 & 1.065389 & 0.443705 \\
Kurtosis & 2.885474 & 2.867090 & 2.874854 & 2.268130 \\
Jarque-Bera & 0.025049 & 8.281855 & 8.542264 & 2.480870 \\
Probability & 0.987554 & 0.015908 & 0.013966 & 0.289258 \\
Sum & 1224.224 & 1241.418 & 1264.848 & 115.4400 \\
Sum & & & & \\
Sq. Dev. & 40.35444 & 136.0191 & 117.6790 & 104.0213 \\
Observations & 45 & 45 & 45 & 45 \\
$\quad$ Cross sections & 5 & 5 & 5 & 5 \\
\hline Sumber: Output Eviews10, & & & &
\end{tabular}

Sumber: Output Eviews10, 2020

Berdasarkan hasil tabel deskripsi statistik diketahui bahwa jumlah observasi dalam penelitian ini sebanyak 45. kemudian mean atau rata-rata dari variabel X1 (Dana Pihak Ketiga) pada Unit Usaha Syariah di Indonesia yang menjadi sampel penelitian selama periode 2010 2020 adalah sebesar 27,58707 dengan standar deviasi sebesar 1,758221. Untuk nilai maksimum Dana Pihak Ketiga sebesar 31,30671, dan untuk nilai minimum sebesar 24,91730 .

Untuk mean atau rata-rata variabel X2 (Total Aset) pada Unit Usaha Syariah di Indonesia yang menjadi sampel penelitian selama periode 20102020 adalah sebesar 28,10773 dengan standar deviasi 1.635397. Nilai maksimum sebesar 31.63325 dan untuk nilai minimum sebesar 25.91444. Untuk mean atau rata-rata variabel X3 (Non-performing Financing) pada Unit Usaha Syariah di Indonesia yang menjadi sampel penelitian selama periode 2010-2020 adalah sebesar 2.565333 dengan standar deviasi 1.537570. Nilai maksimum sebesar 5.800000 dan untuk nilai minimum sebesar 0.090000 . Untuk mean atau rata-rata variabel $\mathrm{Y}$ (Total Pembiayaan) pada Unit Usaha Syariah di Indonesia yang menjadi sampel penelitian selama periode 2010-2020 adalah sebesar 27.20497 dengan standar deviasi 0.957678. Nilai maksimum sebesar 29.08217 dan untuk nilai minimum sebesar 24.81583 .

\section{Pengujian Model Regresi Data Panel}

Pada penelitian ini hanya menggunakan model regresi fixed effect. Untuk menentukan model Fixed Effet atau Common Effect yang paling tepat digunakan dalam mengestimasi data panel, maka dilakukan Uji Chow (Chow test). Ketentuannya, apabila probabilitas $=0,05$ maka $\mathrm{H} 0$ diterima, artinya model common effect (pool least square) yang akan digunakan. Tetapi jika nilai probabilitas < 0,05, maka H1 diterima, berarti menggunakan pendekatan fixed effect. Hasil uji Chow dalam penelitian ini adalah:

\section{Tabel 2. Uji Chow}

Redundant Fixed Effects Tests

Pool: DATA

Test cross-section fixed effects

\begin{tabular}{llll}
\hline Effects Test & Statistic & d.f. & Prob. \\
\hline Cross-section F & $37.794898(4,37)$ & 0.0000
\end{tabular}

Hasil uji chow pada tabel menunjukkan nilai probabilitas cross section $\mathrm{F}=0,0000<0,05$. sehingga $\mathrm{H} 0$ ditolak dan $\mathrm{H} 1$ diterima, artinya model fixed effect yang tepat digunakan dibandingkan dengan common effect untuk mengestimasi data panel. Berikut adalah hasil uji regresi data panel menggunakan metode fixed effect: 
Tabel 3. Model fixed effect

\begin{tabular}{lllll}
\hline Variable & Coefficient & Std. Error & t-Statistic & Prob. \\
\hline C & -1.988949 & 2.034549 & -0.977587 & 0.3346 \\
DPK? & 0.253149 & 0.123498 & 2.049814 & 0.0475 \\
TA? & 0.794344 & 0.128549 & 6.179288 & 0.0000 \\
NPF? & -0.045579 & 0.049313 & -0.924276 & 0.3613 \\
Fixed & & & & \\
Effects (Cross) & -2.226516 & & & \\
BPDDKI-C & 0.431351 & & \\
BPDKALSEL-C & 0.589759 & & & \\
BPDDIY_C & 0.301208 & & & \\
BPDKALTRA-C & 0.904198 & & & \\
BPDSUMBAR-C & & & & \\
\hline
\end{tabular}

Effects Specification

Cross-section fixed (dummy variables)

Weighted Statistics

\begin{tabular}{llll}
\hline R-squared & 0.959130 & Mean dependent var & 58.48393 \\
Adjusted R-squared & 0.951398 & S.D. dependent var & 32.25522 \\
S.E. of regression & 0.415813 & Sum squared resid & 6.397317 \\
F-statistic & 124.0444 & Durbin-Watson stat & 1.563737 \\
Prob(F-statistic) & 0.000000 & & \\
\hline
\end{tabular}

Unweighted Statistics

\begin{tabular}{llll} 
R-squared & 0.773262 & Mean dependent var & 27.20497 \\
Sum squared resid & 9.149894 & Durbin-Watson stat & 0.985432 \\
\hline
\end{tabular}

Sumber: Output eviews 10,2020

Berdasarkan hasil estimasi untuk model regresi data panel fixed effect secara statistik variabel Dana Pihak Ketiga dan Total Aset berpengaruh signifikan, dimana nilai probabilitas Dana Pihak Ketiga sebesar 0,0475 lebih kecil dari $\alpha=0,05$ dan nilai probabilitas Total Aset adalah sebesar 0,0000 lebih kecil dari $\alpha=0,05$. Variabel Non Perfroming Financing tidak berpengaruh signifikan, dimana nilai probabilitas Non Perfroming Financing adalah sebesar 0,3613 lebih besar dari $\alpha=0,05$.

\section{Uji Asumsi Klasik \\ Uji Normalitas}

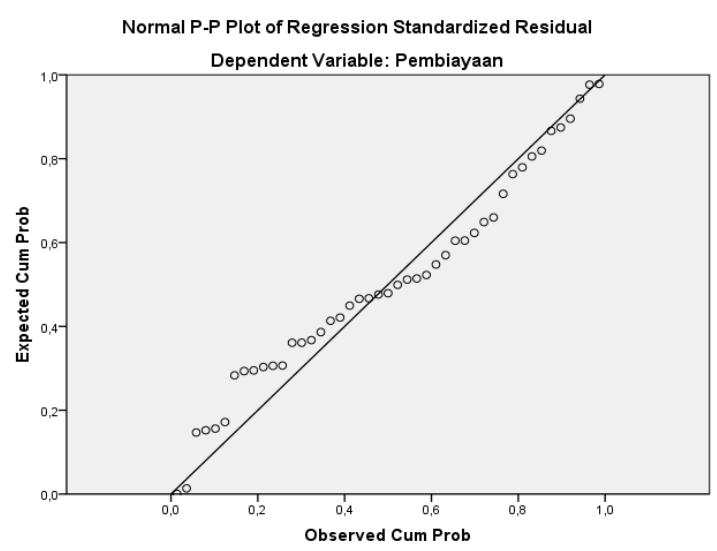

Gambar 2. Hasil Uji Normalitas (P-P Plot) Sumber: Data Hasil Penelitian (diolah) tahun 2020 
Hasil data SPSS dengan grafik P-P plot menunjukkan data yang menyebar disekitar garis normal dan mengikuti garis diagonal atau grafik histogramnya menunjukkan pola distribusi normal, sehingga dapat disimpulkan bahwa model regresi tersebut memenuhi asumsi normalitas. Dasar pengambilan Keputusan dalam Uji Normalitas K-S

1. Jika nilai signifikansi (Sig.) lebih besar dari 0,05 maka data penelitian berdistribusi normal.

2. Sebaliknya, Jika nilai signifikansi (Sig.) lebih kecil dari 0,05 maka data penelitian tidak berdistribusi normal.

Tabel 4. Hasil Uji Normalitas (One-Sample KS)

One-Sample Kolmogorov-Smirnov Test

\begin{tabular}{lll}
\hline & & $\begin{array}{l}\text { Unstandardized } \\
\text { Residual }\end{array}$ \\
\hline N & & 45 \\
Normal & Mean &,- 0000285 \\
Parameters ${ }^{\mathrm{a}, \mathrm{b}}$ & Std. & $4,21060457 \mathrm{E} 11$ \\
& Deviation & \\
Most & Absolute &, 143 \\
Extreme & Positive &, 090 \\
Differences & Negative &,- 143 \\
Kolmogorov-Smirnov Z &, 959 \\
Asymp. Sig. (2-tailed) &, 317 \\
$\begin{array}{l}\text { a. Test distribution is Normal. } \\
\text { b. Calculated from data. }\end{array}$ \\
\hline
\end{tabular}

Pada Tabel nilai Asymp. Sig. (2-tailed) sebesar 0,317 dan lebih dari 0,05 maka data terdistribusi dengan normal. Sehingga penelitian ini telah memenuhi uji asumsi normalitas.

\section{Uji Multikolonieritas}

Tabel 5. Coefficients ${ }^{\mathrm{a}}$

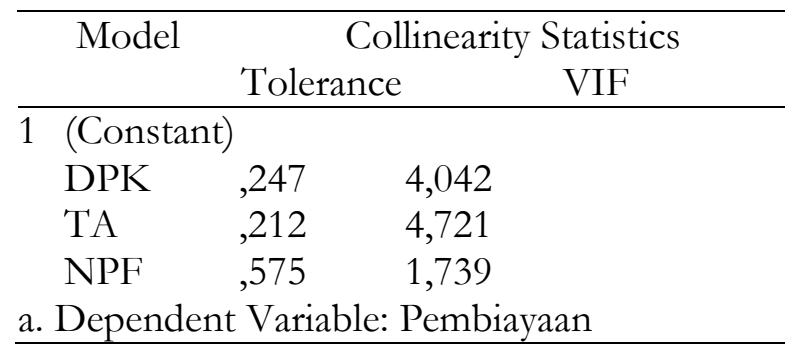

Dasar pengambilan keputusan dari uji tolerance dan VIF adalah jika nilai tolerance lebih besar dari 0,10 maka tidak terjadi multikolinieritas. Sebaliknya, jika nilai VIF lebih kecil dari 10,00 maka tidak terjadi multikolinieritas. Pada Tabel 4.6 nilai tolerance DPK sebesar 0,247 TA sebesar 0,212 , dan NPF sebesar 0,575 , nilai tolerance ini lebih besar dari 0,10. Sedangkan pada nilai VIF DPK sebesar 4,042 TA sebesar 4,721, dan NPF sebesar 1,739, nilai VIF ini lebih kecil dari 10,00. Dapat disimpulkan bahwa dalam penelitian ini tidak terjadi korelasi yang kuat, sehingga telah memenuhi uji asumsi multikolinieritas.

\section{Uji Heteroskedastisitas}

Tabel 6. Coefficients ${ }^{\mathrm{a}}$

\section{Model}

\begin{tabular}{llll} 
& & $\mathrm{t}$ & Sig. \\
\hline 1 (Constant) & 69,074 &, 000 \\
DPK & 1,559 &, 127 \\
TA & 1,959 &, 057 \\
NPF & $-3,901$ &, 000
\end{tabular}

a. Dependent Variable: LN_RES2

Dasar pengambilan keputusan dalam uji Heterokedasitas adalah jika nilai sig. Lebih besar dari 0,05 maka tidak terdapat gejala heterokedasitas. Pada Tabel 4.7 nilai sig. DPK sebesar 0,127 TA sebesar 0,057 dan NPF sebesar 0,000. Nilai sig. Ini lebih besar dari 0,05. Dapat dilihat jika NPF terjadi heteroskedastisitas dikarenakan nilai sig. $<0,05$ dan variabel DPK serta TA tidak terjadi heteroskedastisitas dikarenakan nilai sig. $>0,05$ yaitu sebesar 0,127 dan 0,057 .

\section{Uji Autokorelasi}

\begin{tabular}{ll}
\multicolumn{2}{c}{ Tabel 7. Runs Test } \\
\hline Test Value & \multicolumn{2}{c}{ Unstandardized Residual } \\
Cases & $-2,27650 \mathrm{E} 10$ \\
$<$ Test Value & 22 \\
Cases & 23 \\
$>=$ & Test \\
Value & \\
Total Cases & 45 \\
Number & 18 \\
of Runs & \\
Z & $-1,505$ \\
Asymp. & 132 \\
Sig. (2-tailed) & \\
a. Median &
\end{tabular}


Berdasarkan tabel 7 diatas dapat dilihat hasil uji Runtest menunjukkan nilai Asymp. Sig. (2-tailed) sebesar 0,132 lebih besar daripada nilai $\alpha$ sebesar 0,05 sehingga hasil ini menunjukkan nilai bersifat acak.

\section{Uji Koefisien Determinasi}

Tabel 8. Model Summary

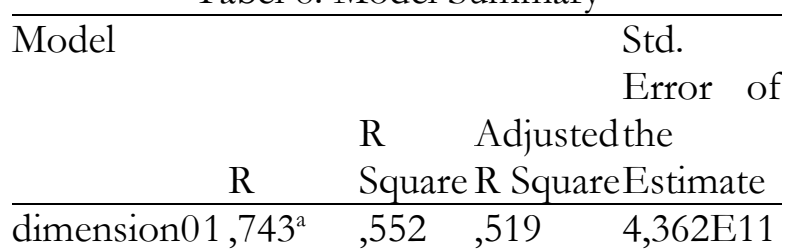

a. Predictors: (Constant), NPF, DPK, TA

Sumber: Output Eviews10, 2020.

Berdasarkan Tabel 4.8 R Square menunjukkan 0,519 atau $51,9 \%$. Hal ini membuktikan bahwa jika DPK, TA dan NPF secara simultan dapat menjelaskan sebesar 51,9\% terhadap faktor yang mempengaruhi pembiayaan berbasis bagi hasil.

\section{Uji Hipotesis}

\section{Uji F}

Nilai F tabel dapat dilihat pada tabel F statistik pada df $1=$ jumlah variabel-1 atau 3-1 = 2 dan df $2=n-k-1$ atau 45-3-1 = 41 ( $\mathrm{k}$ adalah jumlah variable independen). Dengan signifikansi 0,05 diperoleh hasil $\mathrm{F}$ table $=2,83$. Hasil Uji $\mathrm{F}$ ditampilkan dalam tabel sebagai berikut:

Tabel 9. Effects Specification

Cross-section fixed (dummy variables)

Weighted Statistics

\begin{tabular}{|c|c|c|}
\hline & Mean & \\
\hline R-squared & 0.959130 dependent var & 58.48393 \\
\hline Adjusted & S.D & \\
\hline R-squared & 0.951398 dependent var & 32.25522 \\
\hline S.E. & Sum & \\
\hline of regressior & 0.415813 squared resid & 6.397317 \\
\hline F-statistic & $\begin{array}{l}\text { Durbin- } \\
\text { 124.0444 Watson stat }\end{array}$ & 1.563737 \\
\hline $\begin{array}{l}\text { Prob(F- } \\
\text { statistic) }\end{array}$ & 0.000000 & \\
\hline
\end{tabular}

Sumber: Output Eviews10, 2020.

Berdasarkan hasil uji $\mathrm{F}$ di atas terlihat bahwa nilai $\mathrm{F}$ hitung $>\mathrm{F}$ tabel $(124.0444>2,83)$ dengan tingkat Prob (F-Statistic) 0,000. Dengan menggunakan tingkat $\alpha 0.05$ atau $5 \%$ maka $\mathrm{H}_{0}$ ditolak. Sehingga dapat disimpulkan bahwa terdapat pengaruh secara simultan pada variabel Dana Pihak Ketiga, Total Aset dan Nonperforming Financing.
Uji t

\begin{tabular}{|c|c|c|}
\hline & abel to. Hasil U1 & \\
\hline \multirow[b]{2}{*}{ Variable } & Coefficie Std. & Prob. \\
\hline & Error & Statistic \\
\hline
\end{tabular}

C $\quad-1.9889499 \quad 7 \quad 6$

2.034540 .977580 .334

DPK?

0.123492 .049810 .047

TA?

$\begin{array}{llll}0.253149 & 8 & 4 & 5\end{array}$

0.128546 .179280 .000

$\begin{array}{llll}\text { TA? } & 0.7943449 & 8 & 0\end{array}$

0.049310 .924270 .361

NPF? $\quad-0.0455793 \quad 6 \quad 3$

Fixed Effects

(Cross)

BPDDKI-C -2.226516

BPDKALSEL

$\begin{array}{ll}-\mathrm{C} & 0.431351\end{array}$

BPDDIY-C 0.589759

BPDKALTRA

-C 0.301208

BPDSUMBAR

-C $\quad 0.904198$

Sumber: Output Eviews10, 2020.

Dari uji $\mathrm{t}$ di atas dapat disimpulkan bahwa:

1. Variabel Dana Pihak Ketiga secara parsial berpengaruh positif signifikan terhadap Total Pembiayaan berbasis bagi hasil. Hal ini karena nilai thitung bernilai positif 2,049814 lebih besar dari $t_{\text {tabel }} 2.01954$ dan probabilitas kurang dari 0,05 dimana nilai probabilitasnya sebesar 0,0475 kurang dari 0,05 sehingga Ha diterima dan Ho ditolak.

2. Variabel Total Aset secara parsial berpengaruh positif signifikan terhadap Total Pembiayaan berbasis bagi hasil. Hal ini karena nilai $t_{\text {hitung }}$ bernilai positif 6,179288 lebih besar dari tabel 2.01954 dan probabilitas kurang dari 0,05 dimana nilai probabilitasnya yakni sebesar 0,00 lebih kecil dari 0,05 sehingga $\mathrm{Ha}$ diterima dan $\mathrm{Ho}$ ditolak.

Variabel Non-performing Financing secara parsial berpengaruh negatif tidak signifikan terhadap Total Pembiayaan berbasis bagi hasil. Hal ini karena nilai thitung bernilai 0,924276 lebih kecil dari tabel 2.01954 dan probabilitas lebih dari 0,05 dimana nilai probabilitasnya yakni sebesar 0,3613 lebih besar dari 0,05 sehingga $\mathrm{Ha}$ ditolak dan $\mathrm{Ho}$ diterima. 


\section{Kesimpulan dan Saran}

\section{Kesimpulan}

1. Pada penelitian ini, peneliti menggunakan estimasi model regresi fixed effect. Model ini didapatkan setelah dilakukan uji Chow dan uji Haustman sebagaimana output yang dihasilkan dapat dilihat pada bab pembahasan. Dalam penelitian ini peneliti menggunakan kriteria dalam pengambilan sampel bukan dilakukan secara acak oleh karena itu metode yang lebih baik digunakan adalah fixed Effect.

2. Hasil pengujian variabel dana pihak ketiga secara parsial berpengaruh positif signifikan terhadap total pembiayaan berbasis bagi hasil pada unit usaha syariah di Indonesia karena dengan bertambahnya aliran dana pihak ketiga yang masuk kedalam kas bank syariah yang dapat dimanfaatkan bank maka akan semakin meningkatkan pula pembiayaan yang disalurkan oleh bank syariah kepada masyarakat, hal ini sejalan dengan penelitian yang diakukan oleh (Barizi et al., 2021)semakin besar simpanan atau sumber dana yang terhimpun maka bank akan dapat menyalurkan pembiayaan lebih banyak(Putri \& Purwohandoko, 2021).

3. Hasil pengujian variabel total aset secara parsial berpengaruh positif signifikan terhadap total pembiayaan berbasis bagi hasil pada unit usaha syariah di Indonesia karena aset bank merupakan salah satu tolak ukur seberapa besar pembiayaan dapat disalurkan, dengan tingginya nilai aset bank akan mampu untuk memperbaiki struktur modal yang cukup dan menjamin risiko-risiko dari penempatan aset-aset produktif, salah satunya adalah pembiayaan sehingga dapat disimpulkan bahwa semakin tinggi nilai aset maka semakin besar pula tingkat pembiayaan yang dapat disalurkan ke masyarakat. Hal ini sejalan dengan peneliti sebelumnya,(melisa andriyani \& Indriyani, 2021).

4. Hasil pengujian variabel Non-performing Financing secara parsial berpengaruh negatif tidak signifikan terhadap total pembiayaan berbasis bagi hasil pada unit usaha syariah di Indonesia karena tingkat non-performing financing yang tinggi menyebabkan tidak berjalannya fungsi bank secara optimal dan menurunkan laju perputaran aliran kas bank yaitu profitabilitas serta apabila non-performing financing terus mengalami peningkatan hingga mencapai skala 5\% maka bank tidak dapat menyalurkan pembiayaannya, sehingga hal ini mempengaruhi kemampuan bank dalam menyalurkan pembiayaannya kepada masyarakat. Hal ini sejalan dengan peneliti sebelumnya (Manaf \& Bawono, 2019).

5. Hasil pengujian dari ketiga variabel dana pihak ketiga, total aset dan non-performing financing secara bersama-sama berpengaruh secara simultan terhadap total pembiayaan berbasis bagi hasil pada unit usaha syariah di Indonesia hasil ini dapat dilihat pada bab pembahasan. nilai $\mathrm{F}_{\text {hitung }}>\mathrm{F}_{\text {tabel }}(124.0444>$ 2,83) dengan tingkat Prob (F-Statistic) 0,000. Dengan menggunakan tingkat $\alpha 0.05$ atau $5 \%$ maka $\mathrm{H}_{0}$ ditolak. Sehingga dapat disimpulkan bahwa terdapat pengaruh secara simultan antar masing masing variabel.

\section{Saran}

1. Perbankan syariah perlu memiliki strategi yang efektif untuk menurunkan tingkat nonperforming financing agar likuiditas bank syariah tetap terjaga. Cara lain adalah dengan meningkatkan total pembiayaan dan juga meningkatkan dana pihak ketiga

2. Bagi penelitian selanjutnya diharapkan dapat melanjutkan dan menambah jumlah sampel dengan menambah BPRS serta jumlah tahun dengan menambahkan moderating atau intervening.

\section{Daftar Pustaka}

Alfonso, T. D., \& Diana, N. (2021). YUME: Journal of Management Pengaruh CAR, NPF dan FDR Terbadap ROA Pada perusabaan perbankan Syariah yang terdaftar di Bursa Effect Indonesia tabun 2010-2019. 4(3), 543-558. https://doi.org/10.37531/yume.vxix.464 6

Barizi, T., Fatoni, R., Fitrowati, Z., \& Khasanah, U. (2021). Moderasi NPF terhadap Intervensi BOPO dan CAR pada Kinerja Keuangan Bank Syariah di Indnesia 20192021. Al-Kharaj: Jurnal Ekonomi, Keuangan \& Bisnis Syariah, 4(2), 328-344. https://doi.org/10.47467/alkharaj.v4i2.6 51. 
Gusnetti. (1967). 済無No Title No Title No Title. In Angewandte Chemie International Edition, 6(11), 951-952. https://www.ojk.go.id/Files/201403/pbi _082106_1395129217.pdf

Harianto, S. (2017). Rasio Keuangan dan Pengaruhnya Terhadap Profitabilitas Pada Bank Pembiayaan Rakyat Syariah. Esensi, 7(1), 41-48. https://doi.org/10.15408/ess.v7i1.4076

Haryani, J., \& Wiratmaja, I. D. N. (2014). Pengaruh Ukuran Perusahaan, Komite Audit, Penerapan Dan International Financial Reporting Standards Dan Kepemilikan Publik Pada Audit Delay. EJurnal Akuntansi Universitas Udayana, ISSN: 2302-8556, 6(1), 63-78.

Mahdawi, Triyono, Sinaga, S., Collyn, D., Zalukhu, R. S., Saputra, J., Ilham, R. N., \& Harianto, S. (2021). Analyzing the banks' performance through financial statements: An application of the modified du pont method. Proceedings of the International Conference on Industrial Engineering and Operations Management, 5593-5600.

Manaf, M. A., \& Bawono, A. (2019). Pengaruh SIMA, NPF Dan CAR Terhadap Profitabilitas (ROA) Dengan FDR Sebagai Variabel Intervening Pada Bank Umum Syariah Periode 2016-2019. 160-175.

Melisa andriyani, fanfaktor-F. Y. M. I. M. S. I. P. B. U. S., \& Indriyani, M. (2021). FaktorFaktor Yang Mempengarubi. 11, 224-239.
Meutia, I., Harianto, S., \& Fata, K. (2019). Pengaruh Pembiayaan Murabahah, Mudharabah, Dan Biaya Operasional Terhadap Return on Asset Bank Umum Syariah Dan Unit Usaha Syariahdi Indonesia. El-Amwal, 1(2), 1. https://doi.org/10.29103/elamwal.v1i2.1347

Nofi Zumaidah, L., \& Soelistyo, A. (2018). Pengaruh Total Aset, Dana Pihak Ketiga, dan Kredit Pada Bank Umum Terhadap Pertumbuhan Ekonomi Provinsi Provinsi di Indonesia Pada Tahun 2013 2016. Jurnal Ilmi Ekonomi, 2Nofi Zuma, 251-263.

Putri, D. P., \& Purwohandoko. (2021). Pengaruh Dana Pihak Ketiga, CAR, NPF dan FDR terhadap ROA pada Bank Syariah yang Terdaftar pada Bursa Efek Indonesia. Journal of Economics and Business Innovation, 1(1), 1-13.

Umum, B. (2021). Pengaruh DPK, CAR , dan Pendapatan Bagi Hasil terbadap Pembiayaan Berbasis Bagi Hasil dengan NPF sebagai Variabel Moderating. 3(5), 909-924.

Wahyuningtyas, I. P., \& Utami, V. F. (2021). Analisis Pengaruh Dana Pihak Ketiga (DPK), Non-performing Financing (NPF) dan Return On Asset (ROA) terhadap Pembiayaan di PT Bank Muamalat Indonesia Tbk. El-Jigya: Jurnal Ekonomi Islam, 9(2), 171-185. https://doi.org/10.24090/ej.v9i2.5170. 